\title{
PENGARUH TERAPI BEAPREASI (KOMBINASI SENAM OTAK DENGAN RELAKSASI BENSON) TERHADAP KUALITAS TIDUR PADA LANJUT USIA DENGAN INSOMNIA
}

\author{
Wulansari $^{1}$, Mukhamad Mustain ${ }^{1}$, Fiktina Vifri Ismiriyam ${ }^{1}$ \\ ${ }^{1}$ Prodi D3 Keperawatan, Fakultas Keperawatan, Universitas Ngudi Waluyo, Semarang \\ wulan_disha@yahoo.co.id
}

\begin{abstract}
Abstrak
Kualitas tidur pada lansia yang mengalami insomnia sangat bervariasi yaitu ada yang baik dan ada yang buruk. Salah satu keluhan tidur lansia adalah Insomnia, dimana ini merupakan suatu proses degenerasi pada lansia menyebabkan waktu tidur yang efektif semakin berkurang, dan menyebabkan tidak tercapainya kualitas tidur yang adekuat. Intervensi yang diberikan dapat disisipkan dalan kegiatan Posbindu. Salah satu Intervensi yang dapat diberikan adalah terapi beapreasi. Penelitian ini bertujuan untuk mengetahui ada atau tidaknya pengaruh terapi Beapreasi terhadap kualitas tidur pada lansia dengan insomnia di Posbindu Kemuning Kelurahan Candirejo Ungaran. Design penelitian yang digunakan adalah quasi experiment pre-test post-test with control group dan dilakukan pada 128 responden yang terbagi kedalam kelompok eksperimen dan kelompok kontrol, masing-masing kelompok terdiri dari 64 responden. Metode yang digunakan untuk menentukan responden adalah teknik purposive sampling. Penilaian Kualitas tidur di ukur dengan kuesioner PSQI dan dilakukan 2 kali pengukuran yaitu sebelum dan sesudah diberikan terapi Beapreasi. Penelitian menunjukkan bahwa rerata nilai PSQI pada kelompok eksperimen sebelum dilakukan intervensi sebesar 6.27 dan rerata nilai PSQI pada kelompok kontrol sebesar 5.15. Selanjutnya rerata nilai PSQI pada kelompok eksperimen setelah dilakukan intervensi sebesar 3.67, sedangkan rerata nilai PSQI kelompok kontrol sebesar 5,73. Terdapat perbedaan nilai PSQI pada kelompok eksperimen dan kontrol dengan nilai $\mathrm{p}$ 0.00 , nilai $\mathrm{p}<0.05$ sehingga ada pengaruh yang bermakna dari pemberian terapi beapreasi terhadap peningkatan kualitas tidur. Intervensi terapi Beapreasi dapat meningkatkan kualitas tidur pada lansia yang mengalami insomnia . Terapi Beapreasi dapat dijadikan salah satu intervensi mandiri perawat dalam merawat lansia yang mengalami insomnia dalam upaya meningkatkan kualitas tidur pada lansia.
\end{abstract}

Kata kunci: Terapi beapreasi , kualitas tidur, PSQI (the pittsburgh sleep quality index), lansia insomnia, posbindu

\begin{abstract}
The Effect of Breapreasi Therapy (combain for brain Gym and benson relaxation) on Sleep Quality in the Elderly with Insomnia. Sleep quality in the elderly who experience insomnia varies greatly, there are good and some are bad. One of the complaints of elderly sleep is Insomnia, which is a degeneration process in the elderly which causes effective sleep time to decrease, and causes inadequate quality sleep. The intervention provided can be inserted in the activities of Posbindu. One of the interventions that can be given is therapy of beapreasi. This study aims to determine whether or not there is an effect of beapreasi therapy on sleep quality in the elderly with insomnia at Posbindu Kemuning, Candirejo Village, Ungaran. The research design used was quasi experiment pre-test post-test with control group and carried out on 128 respondents divided into experimental groups and control groups, each group consisting of 64 respondents. The method used to determine respondents is purposive sampling technique. Assessment of sleep quality was measured by the PSQI questionnaire and carried out 2 measurements, namely before and after being given therapy Beapreasi. The study showed that the mean PSQI value in the experimental group before intervention was 6.27 and the mean PSQI value in the control group was 5.15. Then the mean PSQI value in the experimental group after intervention was 3.67, while the mean PSQI value of the control group was 5.73. There are differences in the PSQI values in the experimental and control groups with a value of $\mathrm{p} 0.00$, the value of $\mathrm{p}<0.05$ so that there is a significant effect of the provision of beapreasi therapy on improving sleep quality. Beapreasi therapy interventions can improve sleep quality in elderly who experience insomnia. Beapreasi therapy can be used as one of the nurse's independent interventions in treating elderly people who experience insomnia in an effort to improve sleep quality in the elderly.
\end{abstract}

Keywords: Beapreasi therapy, sleep quality, psqi (the pittsburgh sleep quality index), elderly insomnia, posbindu 


\section{Pendahuluan}

Penuaan atau proses menjadi tua adalah suatu kondisi yang normal, yang akan ditandai dengan perubahan fisik dan tingkah laku yang dapat diprediksi dan terjadi pada semua orang saat mereka mencapai usia tahap perkembangan kronologis tertentu (Stanley \& Beare, 2007). Dengan bertambahnya usia, akan besar kemungkinan seseorang mengalami permasalah fisik, jiwa, spiritual, ekonomi dan sosial. Masalah yang sangat mendasar pada lanjut usia adalah masalah kesehatan yang merupakan akibat proses degeneratif. Pada proses degenerasi pada lansia, salah satunya menyebabkan waktu tidur yang efektif semakin berkurang, dan menyebabkan tidak tercapainya kualitas tidur yang adekuat dan menyebabkan berbagi macam keluhan tidur (Chasanah,2017).

Proses degenerasi pada lansia menyebabkan waktu tidur yang efektif semakin berkurang, dan menyebabkan tidak tercapainya kualitas tidur yang adekuat dan menyebabkan berbagi macam keluhan tidur. Prevalensi pemenuhan gangguan pemenuhan kebutuhan tidur pada lansia cukup meningkat yaitu sekitar $76 \%$. Kelompok lansia lebih mengeluh mengalami sulit tidur sebanyak $40 \%$, sering terbangun pada malam hari sebanyak $30 \%$ dan sisanya gangguan pemenuhan kebutuhan tidur lain (Amir, 2007). Hasil penelitian Khasanah (2012) menunjukkan bahwa 29 reponden $(29,9 \%)$ memiliki kualitas tidur baik dan 68 responden $(70,1 \%)$ memiliki kualitas tidur buruk atau jelek. Hasil penelitian ini didapatkan data bahwa tidur Lansia di Balai Rehabilitasi Sosial " Mandiri " Semarang, dapat disimpulkan bahwa secara keseluruhan kualitas tidur lansia buruk. Hasil ini dapat digunakan sebagai gambaran bagi perawat untuk bisa memanfaatkan data dalam penelitian ini sehingga mampu melakukan asuhan keperawatan pada lansia terkait kebutuhan istirahat tidur.
Perubahan pola tidur lansia disebabkan perubahan sistem neurologis yang secara fisiologis akan mengalami penurunan jumlah dan ukuran neuron pada sistem saraf pusat. Hal ini mengakibatkan fungsi dari neurotransmiter pada sistem neurologi menurun, sehingga distribusi norepinefrin yang merupakan zat untuk merangsang tidur juga akan menurun. Lansia yang mengalami perubahan fisiologis pada sistem neurologis menyebabkan gangguan tidur (Potter\&Perry,2005; Stanley, 2007).

$$
\text { Perubahan tidur yang }
$$

mempengaruhi kualitas tidur yang berhubungan dengan proses penuaan pada seperti meningkatkan latensi tidur, efisiensi tidur berkurang, bangun lebih awal, mengurangi tahapan tidur nyenyak dan gangguan irama sirkardian, peningkatan tidur siang. Jumlah waktu yang dihabiskan untuk tidur lebih dalam menurun. Lansia melaporkan sering tidur siang dan mengalami kesulitan jatuh tertidur dan tetap tidur (Stanley, 2006; Oliveira, 2010).

Gangguan tidur secara umum merupakan keadaan dimana terjadi perubahan kuantitas dan kualitas tidur yang dapat menimbulkan rasa tidak nyaman dan berdampak pada kualitas dan gaya hidup. Insomnia merupakan salah satu gangguan tidur yang banyak dikeluhkan masyarakat. Insomnia pada lansia disebabkan oleh beberapa faktor, diantaranya adalah faktor status kesehatan, penggunaan obat-obatan, kondisi lingkungan, stress psikologis, asupan nutrisi/diet dan pola hidup (Darmojo dan Martono, 2006). Kualitas tidur merupakan suatu penyusun penting dan bagian yang esensial dari kualitas hidup seseorang (Luo dkk, 2013).

Terdapat beberapa faktor yang mempengaruhi kualitas tidur seseorang, diantaranya adalah : 1)Fisik Kondisi, fisik seseorang sangat erat kaitannya dengan kualitas tidur yang dimilikinya. Terutama pada lansia dengan keluhan ketidaknyamanan fisik seperti batuk, kram 
kaki, pegal-pegal pada tubuh dan perut kembung cenderung mengalami penurunan kualitas tidur . 2)Psikososial Memasuki fase lansia akan membuat seseorang mengalami perubahan dalam hal psikososial. Lansia mudah mengalami kecemasan dan kekhawatiran berlebih serta depresi yang dapat mengganggu tidur mereka, 3)Lingkungan Faktor lingkungan ikut berkontribusi dalam mempengaruhi kualitas tidur seseorang. 4)Gaya Hidup, Gaya hidup tentu memberikan pengaruh yang besar terhadap kualitas tidur seseorang. Terutama pada lansia, tidur siang yang pendek dan diikuti dengan latihan fisik sedang pada sore hari dapat memberikan kualitas tidur yang baik (Wahyuni dkk, 2009). Menghentikan aktivitas fisik seperti hubungan sosial dengan teman, pekerjaan dan berada di dalam kamar sepanjang hari terbukti meningkatkan kemungkinan terjadi insomnia (Leblanc dkk, 2015). Kebiasaan mengkonsumsi alkohol dan merokok, serta minum kopi sebelum tidur dapat mengganggu pola tidur normal (Wahyuni dkk, 2009).

Lansia umumnya ditemukan perubahan berupa kedalaman tidur yang terganggu, sehingga apabila terdapat stimulus dari lingkungan disekitarnya, maka lansia akan lebih sering terbangun dibandingkan dengan orang dewasa muda normal yang terbangun hanya 2-4 kali dalam semalam (Darmojo dan Martono, 2006). Adanya penurunan jumlah total waktu tidur, mudah terbangun di malam hari dan terbangun lebih awal dapat memberikan perasaan tidak segar di pagi hari dan kepuasan tidur yang berkurang (Wahyuni dkk, 2009). Hal tersebut berdampak pada munculnya keluhan mengantuk, keletihan dan mudah jatuh tidur di siang hari. Lansia cenderung pergi ke tempat tidur lebih awal dibandingkan dengan orang dewasa muda (Voinescu dan Tatar, 2015) namun membutuhkan waktu yang lama untuk jatuh tertidur (latensi tidur memanjang) dan lebih sering terbangun di malam hari (Wahyuni dkk, 2008).

Hasil survei awal dengan wawancara terhadap 20 lansia di posbindu "Kemuning" kelurahan candirejo didapatkan data bahwa $70 \%$ diantaranya mengeluh susah tidur di malam hari, pergi tidur antara jam 7 sampai jam 9, tapi ada juga yang tidur jam 10. Lansia mengatakan sering terbangun pada malam hari rata-rata 2-3 kali untuk ke kamar mandi dan setelah itu sulit untuk jatuh tertidur lagi. Kondisi lain yang di alami lansia sehingga terbangun pada malam hari dikarenakan merasakan nyeri, terbangun karena mimpi dan keadaan lingkungan yang berisik. Keluhan lain yang dialami lansia adalah merasa kurang segar setelah bangun di pagi hari, mengantuk di siang hari namun ada 5 lansia yang mengeluh tidak bisa tidur disiang hari walaupun sudah mengantuk serta ada keinginan untuk tidur. Maka diperlukan intervensi untuk meningkatkan kualitas tidur pada lanjut usia yang mengalami insomnia. Salah satu intervensi mandiri yang dapat diberikan adalah terapi Beapreasi.

Tujuan Penelitian ini adalah untuk mengetahui pengaruh Terapi Beapreasi terhadap kualitas tidur pada lansia dengan insomnia di Posbindu kemuning kelurahan candirejo. Adapun luaran yang akan dihasilkan pada penelitian ini adalah adanya alternative intervensi dalam kualitas tidur pada lansia yang mengalami insomnia serta meningkatkan ketrampilan perawat dalam perawatan di komunitas untuk lanjut usia. Intervensi ini bisa diterapkan dalam pemberian asuhan keperawatan pada lansia untuk meningkatkan kualitas tidur lansia dengan insomnia.

\section{Metode}

Design penelitian ini menggunakan desain quasi experiment pre-test post-test with control group design. Penelitian ini dilakukan pada awal bulan Desember 2018 hingga bulan Maret 2019 . Penelian ini dilakukan di 
kelurahan Candireho Ungaran. Sampel pada penelitian ini adalah sebanyak 128 lansia, sampel ini terbagi menjadi 2 yaitu kelompok Kontrol dan kelompok intervensi. Masing-masing kelompok terdiri dari 64 lansia yang mengalami insomnia dengan kualitas tidur baik dan buruk. Lansia insomnia direkrut secara purposif dari skreening oleh peneliti dengan menggunakan kuesioner SPQI pada lansia yang tinggal di kelurahan candirejo Ungaran yang terdiri dari 2 bagian yaitu lansia yang mengikuti kegiatan posbindu dan lansia yang tidak ikut dalam posbindu.

Kriteria inklusi responden adalah (1)lansia warga candirejo dan tinggal di candirejo, (2)mengalami insomnia, (3)kualitas tidur baik atau buruk, (4)usia 60 sampai 90 tahun, (5)mampu melakukan program terapi/ tidak mengalami masalah musculoskeletal, (6)bersedia untuk berpartisipasi penuh selama terapi, (7)tidak dalam kondisi total care. Sedangkan kriteria eksklusi penderita adalah (1)tidak mengalami Insomnia, (2)tidak menjalankan program terapi sesuai aturan. Penelitian dilaksanakan di Wilayah Kelurahan Candirejo Ungaran.

Variabel tingkat Kualitas Tidur dinilai dari yang terdiri dari 7 pertanyaan. Jenis kuesioner yang digunakan adalah kuesioner tertutup yang telah baku di gunakan untuk menilai kualitas tidur. Kuesioner tidak dilakukan uji validitas dan reabilitas karena kuesioner tersebut telah menjadi kesioner baku pada penegakan Kualitas tidur, selain itu oleh pada tahun, kuesioner di uji ulang validitas dan reabilitasnya dan dinyatakan valid serta reliable. Modul Beapreasi yang digunakan merupakan pengembangan dari kombinasi senam otak dan Relaksasi Benson dan telah dilakukan sebelumnya oleh peneliti dalam pengaruhnya terhadap penurunan depresi pada lanjut usia. Penggunaan modul ini sebelumnya sudah di terapkan dalam menurunkan tingkat depresi pada lansia. Modul yang digunakan lebih disimpelkan lagi dengan mengurangi penjelasan yang berlebihan pada gambar. Intervensi pada penelitian ini adalah pelaksanaan diawali dengan penilaian kondisi lansia terkait insomsia baik yang mengalami maupun yang tidak mengalami. Bagi yang mengalami insomnia maka dilanjukan pertanyaan terkait kualitas tidurnya dengan menggunakan kuesioner PSQI.

Tahap selanjutnya adalah mengajarkan terapi Beapreasi kepada lansia yang mengalami insomnia pada kelompok intervensi. Sebelum Terapi Beapreasi diterapkan, diawali dengan pelatihan selama 3 kali pertemuan dengan tiap pertemuan dilakukan pelatihan $2 \mathrm{kali}$ sesi, pada hari ketiga latihan dilakukan penilaian kemampuan dalam pelaksanaan terapi Beapreasi. Selanjutnya lansia yang mampu melakukan diminta melaksanakan terapi ini secara mandiri di rumah dengan aturan 1 kali dalam sehari selama 1 bulan dan selanjutnya pada bulan berikutnya dilakukan penilaian kualitas tidur kembali pada lansia yang mengalami insomnia.

Tiap lansia memiliki modul yang sudah diberikan oleh peneliti pada awal awal pelatihan. Sedangkan pada kelompok kontrol tidak diberikan intervensi khusus apapun tetapi lansia melakukan kegiatan sehari-hari seperti biasa. Untuk mengetahui pengaruh terapi Beapreasi terhadap kualitas tidur dari lansia yang mengalami insomnia dari masing-masing kelompok menggunakan uji wilcoxon, sedangkan untuk mengetahui perbedaan tingkat depresi sesudah intervensi antara kelompok kontrol dan intervensi menggunakan uji Mann-whitney. Hal ini di karenakan data yang ada tidak terdistribusi dengan normal. Semua responden dalam penelitian ini telah memperoleh penjelasan tentang tujuan dan manfaat penelitian. Penjelasan diberikan secara lisan dan tertulis. 


\section{Hasil}

Karakteristik Responden

Subyek dalam penelitian ini terdiri dari dua kelompok dengan masing masing kelompok terdiri dari 64 responden. Karakteristik responden meliputi kategori umur lansia, jenis kelamin, dan kondisi kualitas tidur.

Tabel 1.

Umur dan Jenis Kelamin

\begin{tabular}{crrrr}
\hline Variabel & \multicolumn{2}{c}{ Intervensi $(n=64)$} & \multicolumn{2}{c}{ Kontrol $(\mathrm{n}=64)$} \\
\cline { 2 - 4 } & $\mathrm{f}$ & $\%$ & $\mathrm{f}$ & $\%$ \\
\hline
\end{tabular}

\begin{tabular}{ccccc}
\hline Kategori Umur lansia & & & & \\
\hline a. Elderly & 54 & 84.4 & 55 & 85.9 \\
\hline b. old & 10 & 15.6 & 9 & 14.1 \\
\hline
\end{tabular}

Jenis kelamin

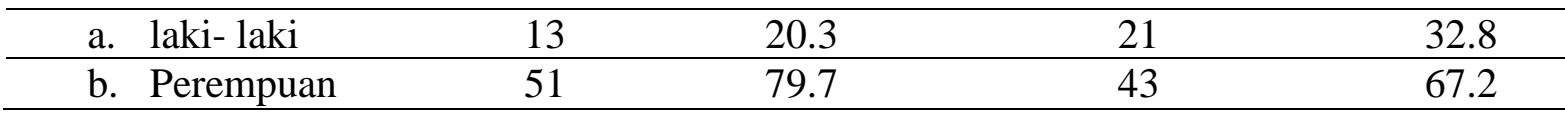

Berdasarkan Tabel 1 didapatkan hasil bahwa Sebagian besar kategori umur lansia adalah elderly yaitu usia 60 tahun hingga 74 tahun. Kategori umur lansia pada kelompok intervensi elderly yaitu mencapai $84.4 \%$ atau 54 lansia. Sedangkan untuk kategori lansia old hanya 15,6\% atau 10 lansia. Pada kelompok kontrol juga Sebagian besar lansia dalan kategori umur elderly dimana mencapai $85.9 \%$ atau 55 lansia. Pada kelompok kontrol jumlah lansia dengan kategori umur old hanya $14.1 \%$ atau 9 lansia. Hal ini juga berbanding lurus dengan jumlah lansia dengan kriteria umur yang ada di masyarakat yaitu kelompok elderly lebih banyak dibandingkan kelompok umur old.
Pada tabel 1 juga di dapatkan didapatkan hasil bahwa Sebagian besar lansia berjenis kelamin perempuan. Pada kelompok intervensi jumlah lansia perempuan mencapai $79.7 \%$ atau 51 lansia. Sedangkan untuk lansia dengan jenis kelamin laki-laki hanya $20.3 \%$ atau 13 lansia. Pada kelompok kontrol juga Sebagian besar berjenis kelamin perempuan yaitu mencapai $67.2 \%$ atau 43 lansia dan jumlah lansia berjenis kelamin laki-laki hanya $32.8 \%$ atau 21 lansia. Hal ini juga berbanding lurus dengan jumlah kategori umur lansia yang ada di masyarakat yaitu lebih banyak lansia yang berjenis kelamin perempuan disbanding laki-laki.

Tabel 2.

Kualitas Tidur

\begin{tabular}{lcccc}
\hline \multicolumn{1}{c}{ Kelompok } & $\mathrm{n}$ & Mean & SD & Min - Maks \\
\hline Intervensi & 64 & 6.27 & 2.11 & $2-10$ \\
Kontrol & 64 & 5.15 & 1.85 & $2-9$ \\
\hline
\end{tabular}

Berdasarkan tabel 2 menunjukkan bahwa rerata kualitas tidur lansia pada kelompok intervensi adalah 6.27 dengan standar deviasi 2.11 . Nilai terendah dari PSQI pada kelompok intervensi adalah 2 dan nilai tertinggi adalah 10 . Sedangkan rerata nilai kualitas tidur lansia pada kelompok kontrol adalah 5.15 dengan standar deviasi 1.85. Nilai kualitas tidur pada kelompok kontrol dengan PSQI pada kelompok intervensi adalah 2 dan nilai tertinggi adalah 9. 
Tabel 3.

Perbedaan PSQI pada kelompok intervensi dan kelompok kontrol Sebelum dan Setelah Intervensi $(n=64)$

\begin{tabular}{lccc}
\hline \multicolumn{1}{c}{ Kelompok } & Mean & SD & Min - Maks \\
\hline Intervensi & & & \\
$\quad$ a. pretest & 6.27 & 2.11 & $2-10$ \\
b. posttest & 3.67 & 1.33 & $1-6$ \\
Kontrol & & & \\
$\quad$ c. pretest & 5.60 & 1.85 & $2-9$ \\
d. posttest & 5.73 & 1.64 & $3-9$ \\
\hline
\end{tabular}

Tabel 3 menunjukkan bahwa rerata nilai PSQI pretest lansia pada kelompok intervensi adalah 6.27 dan Rerata nilai PSQI lansia pada kelompok intervensi pada posttest adalah 3.67. sedangkan
Rerata nilai PSQI lansia pada kelompok kontrol pada saat pretest adalah 5.60 dan Rerata nilai PSQI lansia pada kelompok kontrol pada saat posttest adalah 5.73.

Tabel 4.

Hasil Uji Perbedaan PSQI sebelum dan sesudah intervensi pada kelompok intervensi

\begin{tabular}{llll}
\hline & Mean & SD & $p$ value \\
\hline PSQI sebelum Intervensi & $6.27(2-10)$ & 2.11 & 0.000 \\
PSQI sesudah intervensi & $3.67(1-6)$ & 1.33 & \\
\hline Hasil analisis perbedaan tingkat depresi & dan sesudah pemberian intervensi yaitu \\
sebelum dan sesudah pelatihan mempunyai & Terapi beapreasi, sehingga dapat \\
nilai signifikansi sebesar 0.000, yang lebih & disimpulkan bahwa ada pengaruh dari \\
kecil dibandingkan nilai alpha 0.05. Hal ini & intervensi terhadap nilai PSQI atau \\
dapat menunjukkan bahwa ada perbedaan & perubahan kualitas tidur lansia.
\end{tabular}
yang signifikan pada nilai PSQI sebelum

Tabel 5.

Hasil Uji Perbedaan PSQI sebelum dan sesudah intervensi pada kelompok kontrol

\begin{tabular}{lccc}
\hline & Mean & SD & $p$ value \\
\hline PSQI sebelum Intervensi & 5.60 & 1.85 & 0.33 \\
PSQI sesudah intervensi & 5.73 & 1.64 & \\
\hline
\end{tabular}

Hasil analisis perbedaan tingkat kualitas tidur lansia pada kelompok kontrol mempunyai nilai signifikansi sebesar 0.33 , yang lebih besar dibandingkan nilai alpha 0.05 . Hal ini dapat menunjukkan bahwa tidak dilakukannya intervensi khusus membuat tidak ada perbedaan yang signifikan pada nilai PSQI pada penilaian awal dan penilaian akhir pada kelompok kontrol yang tidak mendapatkan intervensi beapreasi. Sehingga dapat disimpulkan bahwa pada kelompok kontrol atau pada kelompok yang tidak mendapat pelakuan, nilai kualitas tidur cenderung meningkat atau hanya tetap. Sehingga kualitas tidur lansia semakin turun pengaruh dari kegiatan dipanti terhadap nilai PSQI atau kualitas Tidur.

\section{Pembahasan}

Insomnia pada lansia merupakan keadaan dimana individu mengalami suatu perubahan dalam kuantitas dan kualitas pola istirahatnya yang menyebabkan rasa tidak nyaman atau mengganggu gaya hidup yang di inginkan. Gangguan tidur pada lansia jika tidak segera ditangani akan berdampak serius dan akan menjadi gangguan tidur yang kronis. Secara fisiologis, jika seseorang tidak mendapatkan tidur yang cukup untuk mempertahankan kesehatan tubuh dapat 
terjadi efek-efek seperti pelupa, konfusi dan disorientasi (Asmadi, 2008).

Menurut National Sleep

Foundation tahun 2010 sekitar $67 \%$ dari

1.508 lansia di Amerika usia 65 tahun keatas melaporkan mengalami insomnia dan sebanyak 7,3\% lansia mengeluhkan gangguan memulai dan mempertahankan tidur atau insomnia. Kebanyakan lansia beresiko mengalami insomnia yang disebabkan oleh berbagai faktor seperti pensiunan, kematian pasangan atau teman dekat, peningkatan obat-obatan, dan penyakit yang dialami. Di Indonesia insomnia menyerang sekitar 50\% orang yang berusia 65 tahun, setiap tahun diperkirakan sekitar 20\%-50\% lansia melaporkan adanya insomnia dan sekitar $17 \%$ mengalami insomnia yang serius. Prevalensi insomnia pada lansia cukup tinggi yaitu sekitar 67\% (Puspitosari, 2011).

Pada karakteristik umur, sebagian besar lansia masuk criteria lansia elderly taitu yang usianay 60 tahun hingga 74 tahun. Pada karakter jenis kelamin, sebagian besar lansia baik pada kelompok kontrol maupun kelompok intervensi lebih banyak perempuan. Hasil penelitian ini menunjukkan terdapat perbedaan yang signifikan tentang nilai kualitas tidur sebelum dan sesudah dilakukan intervensi terapi beapreasi pada kelompok intervensi. Hal ini sejalan dengang penelitian sebelumnya dengan desain quasi eksperimental menyebutkan bahwa terapi senam otak dengan kombinasi relaksasi benson mampu menurunkan tingkat depresi. Penelitian ini mengungkapkan perbedaan bermakna rata-rata nilai PSQI pada lansia sebelum dan sesudah diberikan terapi ( $p$ value $<0.05$ ).

Terapi individu merupakan terapi yang berfokus pada orang/individu itu sendiri dan aspek lain dalam hidup orang tersebut. Terapi individu merupakan terapi psikoanalisis dan merupakan terapi kesehatan jiwa yang sering digunakan. Terapi senam otak dan Relaksasi Benson merupakan terapi individu dimana kedua terapi ini berfokus pada individu itu sendiri. Terapi individu menurut sebagian ahli merupakan bentuk terapi yang paling akhir dapat dipilih dalam mengatasi masalah kesehatan jiwa. terapi yang dianjurkan adalah terapi yang melibatkan dukungan kelompok atau dukungan kelompok sosial.

Pada kelompok intervensi menunjukkan hasil yang positif atau pengaruh positif dari pemberian terapi beapreasi dalam menurunkan tingkat depresi pada lansia. Pada kelompok kontrol, yang tidak mendapatkan intervensi khusus dalam penatalaksanaan insomnia pada lansia, beberapa lansia mengalami peningkatan nilai PSQI. Hal ini menunjukkan diperlukannya terapi-terapi khusus yang dapat digunakan sebagai intervensi mengatasi insomnia pada lansia.

\section{Simpulan dan Saran}

Intervensi berupa terapi Beapreasi terbukti dapat meningakatkan kualitas tidur pada lansia dengan insomnia hal ini yang terlihat dari penurunan nilai PSQI (The Pittsburgh Sleep Quality Index) pada lansia. Terapi Beapreasi dapat dijadikan salah satu intervensi mandiri perawat melalui pemberdayaan pengelola kegiatan di posbindu sebagai upaya meningkatkan perawatan pada kelompok lansia.

\section{Daftar Pustaka}

Amir, N., 2007. gangguan tidur pada lansia. Cermin Dunia Kedokteran, Jakarta.

Asmadi, 2008., Konsep Dasar Keperawatan. EGC, Jakarta

Astia,N.K.R dan Arianai,N.K.P. 2016. Gambaran kualitas tidur pada lansia di desa adat pecatu kecamatan kuta selatan.https://simdos.unnad.ac.id/p enelitin/5bde595761

Darmojo,B dan Martono,H., 2005. Proses Menua dan implikasi klinik (Buku Ajar Penyakit Dalam). Balai penerbit FKUI:Jakarta, 
Dennison. 2009. Brain GYM (senam Otak). Grasindo, Jakarta

Chasanah, Nur. 2017. Hubungan Kualitas Tidur dengan Kualitas Hidup pada Lansia di Kelurahan Karangasem Kecamatan Laweyan Surakarta. Eprint.ums.ac.id/55437/II/naskah Publikasi

Khasanah, K. dan Hidayati.W. 2012. Kualitas tidur lansia balai rehabilitasi social "Mandiri Semarang". Jurnal nursing studies, Vol1,No1 tahun 2012 hal 189-196. http://ejournal.S1.Undip.ac.id/indekx .php/j nursing.

Leblanc M.F, Desjardins.S, Desgagne.A. 2013. The Relationship Between Sleep Habits, Anxiety and Depression in The Elderly. Dove Press Journal: Nature and science Of Sleep

Luo.J, Zhu G, Zhao Q, Guo Q, Meng H, dkk. 2013.Prevalence and risk factor off poor sleep guality among chine elderly in an urban community result from the shanghai aging study plos one

(11):e812ad01:10.137/journal.pone oo81261

Perry \& Potter. 2005. Buku Ajar Fundamental Keperawatan: konsep, Proses dan Praktik. vol 2 edisi 4 EGC. Jakarta

Perry \& Potter. 2009. Buku Ajar Fundamental Keperawatan: konsep, Proses dan Praktik . EGC. Jakarta

Olivera ,A. 2010. Sleep Quality of Elders living in Long Term Care Institution. http;//www.scielo.br/pdf/reeusp/v44n 3/en_10.pdf

Puspitosari. 2011. Gangguan Pola Tidur Pada Kelompok Usia Lanjut, Journal
Kedokteran Trisakti, Jan - April Vol 2. No 1.

Stenley,M \& Beare,P. 2007. Buku Ajar Keperawatan Gerontik. EGC. Jakarta

Voinescu.B.I \& Tatar.A.S. 2015. Sleep Hygiene awareness; its relation to sleep quality and diurnal preference. Journal of molecular psyichiatry. 3:1

Wahyuni.D., Tjekyan R.M.S., Darmayanti.S. 2009. Kualitas Tidur dan gangguan tidur pada lansia di pantinwerda bakti darma KM 7 Palembang. Fakultas Kedokteran Universitas Sriwijaya 